\title{
Effects of Combination of Diniconazole Fungicide with Antioxidants on Vital Ingredients of Certain Fungi
}

Ali M.M. Shomeet, Ahmed M.I. El-Samadisy, Ramadan M.A. El-Kholy and Ibrahim S. Ibrahim Department of Plant Protection, Fac. of Agric. (Cairo), Al-Azhar University, Egypt

Corresponding author: $\underline{\text { i.said @azhar.edu.eg }}$

\begin{abstract}
The main objective of this study is to evaluate addition of some antioxidants to diniconazole fungicide on the three isolated fungi, i.e., Alternaria alternata, Fusarium graminearum and Pyrenophora tritici-repentis. Three antioxidants, i.e., selenium at 5ppm, butylated hydroxyanisole at 50ppm and ascorbic acid at 100ppm were combined with different concentrations of diniconazole, 0.1, 0.5, 1, 3 and 5ppm, in Potato Dextrose Broth (PDB) medium. The vital ingredients, i.e., fresh weight, total carbohydrates, lipids and proteins of the fungi were determined. The results clearly indicated that fungicide-antioxidant mixtures decreased the vital ingredients of the tested fungi more effectively than the fungicide or antioxidants applied alone. Regardless the isolated fungi, the percent reduction of any of the vital ingredients followed the order; Se $>$ BHA $>$ AsA. These effects increased with increasing the concentration of the fungicide in culture medium. This means that antioxidants, especially selenium, enhanced the fungitoxic activity of diniconazole against the isolated fungi.
\end{abstract}

Keywords: diniconazole, antioxidants, Alternaria alternata, Fusarium graminearum, Pyrenophora triticirepentis.

\section{Introduction}

Fungi, which may attack the seed, root, crown and foliage, cause reduction in crop production. Seed and soil-borne fungi are the most important wheat diseases. Several fungi were recorded as pathogens of seed and root-rot diseases on wheat such as Alternaria alternata, Fusarium spp. (F. culmorum F. graminearum, $F$. equiseti and $F$. solani) Pyrenophora tritici-repentis and Rhizoctonia solani (El-Kholy, 1999, Hashem and Hamada-Afaf, 2002; Atef-Nagwa, 2008; Asran and El-Eraky-Amal, 2011; Harvey et al, 2015 and El-Ballat, 2017).

Several reports illustrated that, the addition of antioxidants to fungicide enhance the activity of fungicide. Butylated hydroxyanisole enhanced the efficacy of difenoconazole, flutolanil, metiram, tetraconazole and trifloxystrobin against $F$. oxysporum, lycopersici, $R$. solani and A. solani. As well as, selenium enhanced the efficacy of azoxystrobin, difenoconazole, metalaxyl and trifloxystrobin against A. solani. Additionally, ascorbic acid and BHA increased the fungitoxic activity of flutolanil, metalaxyl and tetraconazole against $A$. niger, $F$. oxysporum and $P$. chrysogenum (Ali, 2008; Ali, 2013 and Mahmoud-Amira 2016)

The aim of this work is to evaluate addition of certain antioxidants to diniconazole on the fresh weight, total carbohydrates, proteins and lipids of the tested fungi.

\section{Materials and methods}

The present study was carried out in the laboratory of Plant Protection Department, Faculty of Agriculture, Cairo, AL-Azhar University, Egypt during 2016.

\section{Fungicide and antioxidants}

Diniconazole (Sumi eight $2 \%$ WP) was produced by Kafr El-Zayat for Chemicals and Pesticides Co. This fungicide is systemic, belonging to triazole group. The chemical name is $(E)-(R S)-1-$ (2,4-dichlorophenyl)-4,4-dimethyl-2-(1H-1,2,4triazol-1-yl)pent-1-en-3-ol.

The antioxidants were ascorbic acid, AsA, $\left(\mathrm{C}_{6}\right.$ $\left.\mathrm{H}_{8} \quad \mathrm{O}_{6}, 100 \% \mathrm{w} / \mathrm{w}\right)$ provided by Biotech for laboratory chemical Co., butylated hydroxyl-anisole, BHA, $\left(\mathrm{C}_{11} \mathrm{H}_{16} \mathrm{O}_{2}, 100 \% \mathrm{w} / \mathrm{w}\right)$ and selenium, Se, (sodium selenite, $\mathrm{Na}_{2} \mathrm{SeO}_{3} 98.8 \%$ ) were obtained from El-Goumhouria Co.

\section{Fungi}

The fungi were isolated from seeds and roots of wheat according to the method described by Moubarak and Abdel Monaim (2011). These fungi were Alternaria alternata, Fusarium graminerum and Pyrenophora tritici-repentis. Identification of fungal isolates was confirmed by Plant Pathology Dept. Faculty of Agriculture, Cairo, AL-Azhar University, Egypt.

\section{Effect of the antioxidants on fungicide activity}

Fungi were cultured into $250 \mathrm{ml}$ conical flask capacity, containing $100 \mathrm{ml}$ of liquid Potato Dextrose Broth (PDB) medium amended with different concentrations of fungicide alone, separately antioxidants or a mixture of both. The concentrations of fungicide were $0.1,0.5,1,3$ and $5 \mathrm{ppm}$. Ascorbic acid was used at $100 \mathrm{ppm}$ (AsA 100ppm), butylated hydroxyl-anisole at $50 \mathrm{ppm}$ (BHA 50ppm), however selenium at $5 \mathrm{ppm}$ (Se $5 \mathrm{ppm})$. The flasks were incubated at $25 \pm 2^{\circ} \mathrm{C}$ for 10 days. The cultures of fungi were harvested by filtration using Buchner 
funnel and washed thoroughly with distilled water Patil et al. (2011). The fresh weights of the mycelia were determined as milligram. Free cell extracts were obtained by grounding the mycelial matrix with an approximately equal weight of clean sand in mortars under cold condition and extracted with 70 $\%(\mathrm{v} / \mathrm{v})$ ethyl alcohol in case determination of total proteins and total carbohydrates while using chloroform-methanol $3: 1(\mathrm{v} / \mathrm{v})$ in case total lipids David and Van Etten (1966). The obtained slurry was centrifuged at $6000 \mathrm{rpm}$ for 20 minutes. The supernatant was used to determinate the total carbohydrates, lipids and proteins according to Dubois et al. (1956), Zollner and Kirsch (,",",", 1962) and Doumas et al. (1981), respectively.

\section{Results and Discussion}

The results in Table (1) show the effect of tested antioxidants, fungicide used alone and in combinations on fresh weight of Alternaria alternata, Fusarium graminerum and Pyrenophora tritici-repentis. Generally, the fresh weight of fungi decreased by increasing the concentration of diniconazole in culture medium. The effect of diniconazole on $F$. graminerum was higher than $P$. tritici-repentis flowed by $A$. alternata. Fungicideantioxidant mixtures decreased fresh weight of fungi more effectively than the fungicide or antioxidant applied separately. For example, diniconazole alone at $3 \mathrm{ppm}$ reduced fresh weight of A. alternata by $9.98 \%$, interestingly the fresh weight reduced by $13.65 \%$ when AsA 100ppm was added to the fungicide-amended medium, by $15.69 \%$ with addition BHA 50ppm and $20.31 \%$ with Se 5ppm. Diniconazole alone at $5 \mathrm{ppm}$ decreased fresh weight of $F$. graminerum by $32.84 \%$, interestingly it reduced by $34.55,38.79$ and $44.28 \%$ of fresh weight when AsA 100ppm, BHA 50ppm and Se 5ppm were added to the fungicide-amended medium, respectively. The above trend agreed with Ali (2008) who mentioned that mixed difenoconazole at $10 \mathrm{ppm}$ with $5 \mathrm{ppm}$ of BHA decreased fresh weight of $F$. graminerum more effectively than the fungicide or antioxidant applied alone.

Table 1. Effect of diniconazole applied alone or in a mixture with antioxidants on the percent reduction of fresh weight of the tested fungi.

\begin{tabular}{|c|c|c|c|c|c|c|c|}
\hline \multirow{3}{*}{ Fungi } & \multirow{3}{*}{$\begin{array}{l}\text { Antioxidants } \\
\quad(\mathrm{ppm})\end{array}$} & \multicolumn{6}{|c|}{ Fungicide concentrations (ppm) } \\
\hline & & Control $^{*}$ & 0.1 & 0.5 & 1 & 3 & 5 \\
\hline & & \multicolumn{6}{|c|}{ Reduction $\%$ of fungi fresh weight } \\
\hline \multirow{4}{*}{ Alternaria altrnata } & Control $^{* *}$ & 0.00 & 5.20 & 6.91 & 8.45 & 9.98 & 13.31 \\
\hline & AsA100 & 1.62 & 7.74 & 9.13 & 11.52 & 13.65 & 16.13 \\
\hline & BHA50 & 4.69 & 8.28 & 11.43 & 14.08 & 15.69 & 20.48 \\
\hline & Se5 & 6.48 & 10.32 & 13.05 & 17.15 & 20.31 & 24.32 \\
\hline \multirow{4}{*}{$\begin{array}{l}\text { Fusarium } \\
\text { graminerum }\end{array}$} & Control** $^{* *}$ & 0.00 & 21.85 & 24.71 & 27.80 & 30.55 & 32.84 \\
\hline & AsA100 & 8.01 & 24.59 & 26.20 & 30.09 & 32.15 & 34.55 \\
\hline & BHA50 & 10.53 & 27.69 & 29.63 & 32.61 & 35.47 & 38.79 \\
\hline & Se5 & 15.45 & 31.12 & 34.44 & 38.90 & 41.88 & 44.28 \\
\hline \multirow{4}{*}{$\begin{array}{c}\text { Pyrenophora tritici- } \\
\text { repentis }\end{array}$} & Control** $^{* *}$ & 0.00 & 9.28 & 11.62 & 14.14 & 17.03 & 21.17 \\
\hline & AsA100 & 0.63 & 11.08 & 14.05 & 16.39 & 18.11 & 22.79 \\
\hline & BHA50 & 1.84 & 13.42 & 16.76 & 21.26 & 25.13 & 29.09 \\
\hline & Se5 & 4.14 & 15.58 & 17.93 & 22.16 & 25.86 & 32.34 \\
\hline
\end{tabular}

*control: medium without fungicide. ${ }^{* *}$ control: medium without antioxidant.

Generally, the highest percentage reduction of fresh weight was $44.28 \%$ for fungicide at $5 \mathrm{ppm}$ mixed with Se 5pm on $F$. graminerum. It was noted that, addition of $\mathrm{Se} 5 \mathrm{ppm}$ to diniconazole at all concentrations was better than BHA 50ppm flowed by AsA 100ppm.

Results illustrated in Table (2) indicate that increasing the concentration of tested fungicide in culture medium resulted in great reduction of total carbohydrates content of fungi. Also, the potency of fungicide to reduce total carbohydrates content in fungi increased by adding antioxidants to fungicideamended media. The highest effect was at concentration $5 \mathrm{ppm}$ of $\mathrm{Se}$ mixed with $5 \mathrm{ppm}$ of diniconazole against $F$. graminerum, whereas, the carbohydrates reduction percent was $97.36 \%$. These results are in agreement with that obtained by Gowily-Ahlam et al. (1996), who found that thiabendazole- selenium mixtures reduced carbohydrates in A. tenus and $F$. oxysporum rather effectively than thiabendazole alone. El-KhawagaMaie (2006) mentioned that the addition of antioxidants (AsA, BHA and Se) to tetraconazole, penconazole and fenarimol fungicides increased the reductive potency of fungicides to reduce carbohydrates, lipids and proteins of $F$. oxysporum, $P$. tritici-repentis and $R$. solani. 
Table 2. Effect of diniconazole applied alone or in a mixture with antioxidants on the percent reduction of total carbohydrates of the tested fungi.

\begin{tabular}{|c|c|c|c|c|c|c|c|}
\hline \multirow{3}{*}{ Fungi } & \multirow{3}{*}{$\begin{array}{l}\text { Antioxidants } \\
\quad(\mathrm{ppm})\end{array}$} & \multicolumn{6}{|c|}{ Fungicide concentrations (ppm) } \\
\hline & & Control $^{*}$ & 0.1 & 0.5 & 1 & 3 & 5 \\
\hline & & \multicolumn{6}{|c|}{ Reduction $\%$ of fungi total carbohydrates } \\
\hline \multirow{4}{*}{ Alternaria altrnata } & Control $^{* *}$ & 0.00 & 17.92 & 23.99 & 28.29 & 33.94 & 40.20 \\
\hline & AsA100 & 8.08 & 21.69 & 27.41 & 35.48 & 43.15 & 47.25 \\
\hline & BHA50 & 9.99 & 35.01 & 41.89 & 46.25 & 48.99 & 53.01 \\
\hline & $\operatorname{Se} 5$ & 13.25 & 50.76 & 58.11 & 64.89 & 70.64 & 77.48 \\
\hline \multirow{4}{*}{$\begin{array}{l}\text { Fusarium } \\
\text { graminerum }\end{array}$} & Control $^{* *}$ & 0.00 & 14.16 & 16.21 & 27.27 & 38.71 & 44.02 \\
\hline & AsA100 & 5.56 & 42.18 & 50.77 & 59.21 & 64.57 & 71.76 \\
\hline & BHA50 & 7.54 & 69.25 & 73.88 & 67.61 & 82.64 & 87.82 \\
\hline & $\mathrm{Se} 5$ & 9.69 & 87.56 & 91.21 & 92.71 & 95.48 & 97.36 \\
\hline \multirow{4}{*}{$\begin{array}{l}\text { Pyrenophora } \\
\text { repentis }\end{array}$} & Control $^{* *}$ & 0.00 & 14.61 & 17.38 & 19.06 & 26.97 & 36.04 \\
\hline & AsA100 & 4.29 & 30.40 & 36.68 & 44.68 & 53.65 & 59.89 \\
\hline & BHA50 & 7.36 & 53.19 & 63.82 & 68.25 & 75.16 & 80.97 \\
\hline & Se5 & 10.09 & 79.30 & 85.61 & 87.21 & 92.63 & 96.38 \\
\hline
\end{tabular}

*control: medium without fungicide. **control: medium without antioxidant.

Results in the Table (3) indicate that the fungicideantioxidant mixtures reduced total lipids of $A$. alternata, $F$. graminerum and $P$. tritici-repentis rather effectively than the fungicide or antioxidants used alone. It was noted that, effect of diniconazole used alone on $A$. alternata was more effectively than $P$. tritici-repentis and $F$. graminerum at all concentrations. Se at $5 \mathrm{ppm}$ affects all fungi more than BHA at 100ppm and AsA at 50ppm.

Table 3. Effect of diniconazole applied alone or mixed with antioxidants on the percent reduction of total lipids of the tested fungi.

\begin{tabular}{|c|c|c|c|c|c|c|c|}
\hline \multirow{3}{*}{ Fungi } & \multirow{3}{*}{$\begin{array}{l}\text { Antioxidants } \\
\quad(\mathrm{ppm})\end{array}$} & \multicolumn{6}{|c|}{ Fungicide concentrations (ppm) } \\
\hline & & Control $^{*}$ & 0.1 & 0.5 & 1 & 3 & 5 \\
\hline & & \multicolumn{6}{|c|}{ Reduction $\%$ of fungi total lipids } \\
\hline \multirow{4}{*}{ Alternaria altrnata } & control $^{* *}$ & 0.00 & 37.37 & 41.56 & 53.38 & 59.57 & 64.48 \\
\hline & AsA100 & 2,08 & 60.43 & 64.16 & 66.08 & 71.74 & 77.54 \\
\hline & BHA50 & 6.67 & 76.97 & 80.85 & 84.34 & 86.44 & 87.37 \\
\hline & Se5 & 9.50 & 89.68 & 90.03 & 92.53 & 93.45 & 94.48 \\
\hline \multirow{3}{*}{$\begin{array}{l}\text { Fusarium } \\
\text { graminerum }\end{array}$} & Control $^{* *}$ & 0.00 & 9.09 & 9.49 & 10.50 & 15.94 & 25.48 \\
\hline & AsA100 & 6.39 & 13.45 & 19.65 & 26.17 & 33.85 & 40.05 \\
\hline & BHA50 & 8.53 & 38.49 & 43.56 & 46.25 & 49.77 & 55.20 \\
\hline \multirow{5}{*}{$\begin{array}{c}\text { Pyrenophora tritici- } \\
\text { repentis }\end{array}$} & Se5 & 8.81 & 62.05 & 71.64 & 84.15 & 87.39 & 91.14 \\
\hline & Control $^{* *}$ & 0.00 & 22.50 & 26.29 & 29.17 & 35.58 & 37.79 \\
\hline & AsA100 & 2.08 & 27.83 & 33.00 & 35.42 & 47.33 & 50.67 \\
\hline & BHA50 & 6.67 & 59.83 & 62.17 & 71.01 & 83.92 & 86.92 \\
\hline & Se5 & 9.50 & 88.50 & 94.33 & 95.83 & 96.46 & 97.87 \\
\hline
\end{tabular}

*control: medium without fungicide. **control: medium without antioxidant.

Generally, increasing the concentration of tested fungicide, especial with antioxidants, resulted in increasing the reduction of total lipids in isolated fungi. Diniconazole at $3 \mathrm{ppm}$ caused $59.57 \%$ reduction of lipids in the mycelial matrix of $A$. alternata, interestingly, the same concentration reduced lipids by $71.74 \%$ as a result of addition of AsA 100ppm, 86.44\% with BHA 50ppm and $93.45 \%$ by Se $5 \mathrm{ppm}$. As well as, diniconazole alone at $5 \mathrm{ppm}$ caused $25.48 \%$ lipids reduction of $F$. graminerum, but lipids reduction percent increased to $40.05 \%$ by adding AsA $100 \mathrm{ppm}, 55.20 \%$ by BHA 50ppm and $91.14 \%$ with addition of Se 5ppm to diniconazoleamended medium. The obtained results illustrated that a mixture of $5 \mathrm{ppm}$ Se and $5 \mathrm{ppm}$ diniconazole caused highest reduction of lipids $(97.87 \%)$ in the mycelial matrix of $P$. tritici-repentis. Generally, the effect of diniconazole-antioxidants mixture on lipids of A. alternata was higher than $F$. graminerum and P. tritici-repentis.

Results in Table (4) indicate that the reduction of total proteins in mycelia of the tested fungi was positively correlated with increasing the concentration of tested fungicide in culture medium. Concerning the fungicide-antioxidant mixtures, the results showed that the addition of antioxidants to fungicide-amended media increased the potency of the reduction of proteins of the fungal matrix 
compared to fungicide alone. The least reduction percent of proteins was $6.24 \%$ at AsA $100 \mathrm{ppm}$ of $P$. tritici-repentis. On the other hand, the highest reduction percent of proteins was $94.43 \%$ at Se 5ppm mixed with 5 ppm of diniconazole of A. alternata. The above data are in agreement with Ali (2008) who demonstrated that the addition of BHA to difenoconazole and tetraconazole fungicides increased the efficiency of these fungicides to reduce fresh weight, total carbohydrates, lipids and proteins of A. solani, F. oxysporum and $R$. solani. MahmoudAmira (2016) cited that tetraconazole

Table 4. Effect of diniconazole applied alone or mixed with antioxidants on the precent reduction of total proteins of the tested fungi.

\begin{tabular}{|c|c|c|c|c|c|c|c|}
\hline \multirow{3}{*}{ Fungi } & \multirow{3}{*}{$\begin{array}{l}\text { Antioxidants } \\
\text { (ppm) }\end{array}$} & \multicolumn{6}{|c|}{ Fungicide concentrations (ppm) } \\
\hline & & control $^{*}$ & 0.1 & 0.5 & 1 & 3 & 5 \\
\hline & & \multicolumn{6}{|c|}{ Reduction \% of fungi total lipids } \\
\hline \multirow{4}{*}{ Alternaria altrnata } & control $^{* *}$ & 0.00 & 22.64 & 26.14 & 41.51 & 56.24 & 76.01 \\
\hline & AsA100 & 9.63 & 34.32 & 42.32 & 55.88 & 85.89 & 91.77 \\
\hline & BHA50 & 12.67 & 32.88 & 52.20 & 72.06 & 90.39 & 92.21 \\
\hline & Se5 & 15.36 & 42.32 & 62.89 & 77.45 & 92.08 & 94.43 \\
\hline \multirow{4}{*}{$\begin{array}{l}\text { Fusarium } \\
\text { graminerum }\end{array}$} & Control $^{* *}$ & 0.00 & 16.77 & 32.18 & 55.65 & 68.52 & 80.95 \\
\hline & AsA100 & 11.99 & 32.84 & 55.95 & 73.90 & 81.39 & 91.11 \\
\hline & BHA50 & 20.66 & 23.55 & 51.05 & 64.89 & 77.71 & 84.06 \\
\hline & Se5 & 21.45 & 19.18 & 44.00 & 61.95 & 73.12 & 78.68 \\
\hline \multirow{4}{*}{$\begin{array}{l}\text { Pyrenophora tritici- } \\
\text { repentis }\end{array}$} & Control $^{* *}$ & 0.00 & 13.97 & 35.54 & 73.77 & 78.43 & 88.19 \\
\hline & AsA100 & 6.24 & 16.18 & 38.60 & 75.98 & 85.17 & 89.26 \\
\hline & BHA50 & 9.94 & 24.88 & 43.38 & 78.43 & 87.01 & 90.98 \\
\hline & Se5 & 11.56 & 28.43 & 52.57 & 75.98 & 90.38 & 93.61 \\
\hline
\end{tabular}

decreased total carbohydrates, lipids and proteins of A. solani, F. oxysporum and $P$. chrysogenum. The results also showed the appearance of antagonistic effect when Se 5ppm was added to the media containing diniconazole at concentrations 5ppm, where reduction percent of protein content in $F$. graminerum was $80.95 \%$ with diniconazole alone while it was $78.68 \%$ with diniconazole-Se mixtures. The antagonistic effect is not clear, so it need further studies.

The obtained results clearly indicated that a combination of antioxidants with diniconazole increased the efficiency of fungicide against the isolated fungi more effectively than the fungicide or antioxidants applied alone. Increasing the efficiency of fungicide may be attributing to disorder in the mycelial membrane; this may be make the membrane allows by increasing concentration of fungicide into the fungal cells. The mechanism of the synergistic effect of the tested antioxidants is not clearly explained. However, Khan et al., (2001); Atroshi et al., (2002) and Simonetti et al. (2003) reported that antioxidant may make the fungal membrane more leaky and allowing more fungicide to enter into cell of the fungus and leading to leakage of cellular enzymes. Another explanation was reported by Ali (2008) who suggested that antioxidants may be reducing the oxidation of the fungicides which might increase their fungitoxicity.

Generally, the results showed that the addition of antioxidants to diniconazole increased the potency of fungicide to reduce fresh weight, total carbohydrates, lipids and proteins of the isolated fungi which may be explained its mechanism of action.

Finally, this study suggests that the tested antioxidants could be added to diniconazole fungicide to increase the effectively, additionally to reduce environmental pollution.

\section{References}

Ali, W. M. S. 2008. Integrated control of some tomato diseases. Ph.D. Thesis, Fac. of Agric., Al-Azhar Univ.

Ali, W. M. S. 2013. Synergistic action of profenofos insecticide and selenium to some fungicides against tomato early blight (Alternaria solani). Afr. J. Mycol. \& Biotech, 18: 37-53.

Artoshi, F.; Rizzo, A.; Westermarck, T. and AliVehams, T. 2002. Antioxidants nutrients and mycotoxins. Toxicology., 180(2):151-167.

Asran, M. R. and M.I. Eraky, Amal 2011. Aggressiveness of certain Fusarium graminearum isolates on wheat seedling and relation with their Trichothecence production. Plant Pathol. J., 10(1): 36-41.

Atef-Nagwa, M. (2008). Bacillus subtilits and Trichoderma harzianum as wheat inoculants for biocontrol of Rhizoctonia solani. Aust. J. Basic Appl. Sci., 2(4): 1411-1417.

David, G. and J. 1. van etten (1966). Changes in Fungi with Age. Chemical Composition of Rhizoctonia solani and Sclerotium bataticola. Am. J. Soc. Microbiol., (91): 161-168.

Doumas, B. T., D. D. Bayse, R. J. Carter (1981). Candidate reference method for determination 
of total protein in serum. I. Development and validation, II. Tests for transferability. Clin Chem (27): 1642-1654.

Dubois, M., K. A. Gilles and J. K. Hamilton (1956). Colorimetric method for determination of sugars and related substances. Analytical Chemistry, (28):350-356.

El-Ballat, E. M. A (2017). Efficacy of certain wheat fungicides and their side effects. M.Sc. Thesis, Fac. of Agric., (Cairo) Al-Azhar Univ.

El-Khawaga-Maii, A. Y. (2006). Effect of antioxidants on the efficacy of some fungicides. Ph.D. Thesis, Fac. of Science, Al-Azhar Univ.

El-Kholy, R.M.A. (1999). Integrated control of some wheat diseaes. Ph.D. Thesis, Fac. of Agric. (Cairo) Al-Azhar University.

Gowily-Alham, M., M. B. Mahmoud, M. F. AbdelLateef, A. Razak, T. E. Ramadan and A. A. Razak (1996). Influence of selenium, TBZ and their mixture on metabolic activities of some fungi. African J Myco Biotechnol (4): 45-56.

Harvey, I. C., R. A. Craigie and B. L. Mcloy (2015). The control of tan spot of wheat (caused by Pyrenophora tritici-repentis ): a possible emerging disease in New Zealand. New Zealand Plant Protect., 68 : 428-433.

Hashem, M. and Hamada-Afaf M. (2002). Evaluation of two biologically active compounds for control of wheat root rot and its causal pathogens. Microbiol., 30(4): 233-239.

Khan, S. H.; Aked, J. and Magan, N. (2001). Control of the anthrancnose Pathogen of banana (Colletorichum musae) using antioxidant alone and in combination with thiabendazole or imazalil. Plant pathology, 50: 601-608.

Mahmoud-Amira, A. E. (2016) Biological genetic studies on some factors affecting fungal resistant to fungicides. Ph.D. Thesis, Fac. of Agric., (Cairo) Al-Azhar Univ., p 139.

Moubarak, M. Y.1. and M. F. Abdel-Monaim (2011). Effect of bio-control agents on yield, yield components and root rot control in two wheat cultivars at New Valley region, Egypt. J. of Cereals and Oilseeds Vol. 2(6), pp. 77-87.

Patil, S., S. Sriram., M. J. Savitha and N. Arulmani (2011). Induced systemic resistance in tomato by non-pathogenic Fusarium species for the management of Fusarium wilt. Archives of Phytopathology and Plant Protect., (44): 16211634.

Simonetti, G., N. Simonetti and A. Villa, (2003). Increase of activity of tiboconazole against resistant microorganisms by the addition of butylated hydroxyanisole. Int. J. of Antimicrobial Agents 22 (4): 439-443.

Zollner, N. and K. Kirsch (1962). Determination of total lipids. Z. ges. Exp. Med.

$$
\begin{aligned}
& \text { تأثير خلط مبيد الفطر دينكونازول مع مضادات الأكسدة على المكونات الحيوية لبعض الفطريات }
\end{aligned}
$$

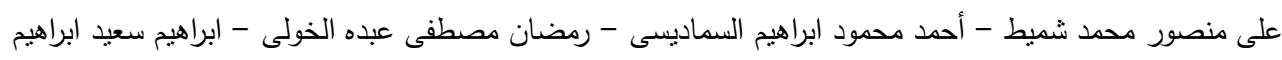

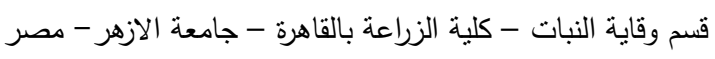

\footnotetext{
Alternaria تهدف هذه الدراسة إلى تقييم تأثير إضافة بعض مضادات الأكسدة إلى مبيد الفطر دينكونازول على الفطريات الثلاثة

alternata, Fusarium graminearum and Pyrenophora tritici-repentis.

جزء في المليون، بيونيل هيدروكسي أنسول بتركيز 50 جزء في المليون وحامض الأسكوربك عند 100 جزء في المليون (كلٍ على حدى) مع

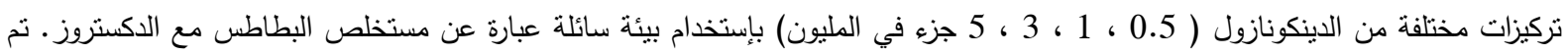
تقدير المكونات الحيوية، الوزن الغض والمحتوى الكلى للكربوهيدرات والبروتينات والدهون للفطريات المعزولة. أثنارت النتائج بوضوح إلى أنى أن فئن

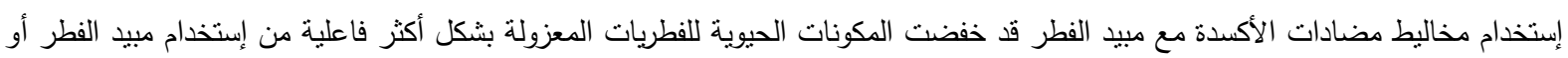
مضادات الأكسدة بشكل منفرد. وبغض النظر عن الفطريات المعزولة، فإن انخفاض نسبة المكونات الحيوية كان أكبر فى حالة إستخدام السيلينيوم

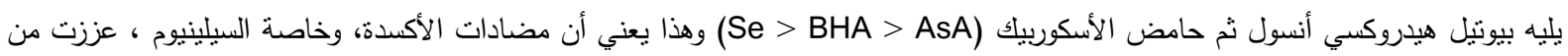
فعالية الدينكونازول ضد الفطريات المعزولة.
} 